\title{
EVALUATING TOBACCO ADVERTISING VIOLATIONS AND IT'S CONTRIBUTION TO LOCAL REVENUE IN MAKASSAR
}

\author{
Musyarrafah Hamdani ${ }^{1}$, Sri Wahyuni ${ }^{1}$, Ismi ${ }^{1}$, M. Alimin Maidin', Ahmad Wadi ${ }^{1}$, Hadijah Hasyim ${ }^{1}$, \\ Ahmad Mawardi Shabir ${ }^{1}$ \\ ${ }^{1}$ Hasanuddin Center for Tobacco Control and NCDs Prevention \\ (Hasanuddin CONTACT), Faculty of Public Health, Hasanuddin University, Makasar, Indonesia \\ Correspondence address: Musyarrafah Hamdani \\ Email: arahamdani11@gmail.com
}

\begin{abstract}
Around 50.82\% of the age group 15-19 years were smokers in Makassar city, one of which was influenced by tobacco ads exposure (National Institute of Health Research and Development, 2019b). This study aimed to evaluate the violation of tobacco product advertising to Local Regulation of South Sulawesi No. 1 of 2015 on Smoke-Free Area (SFA) in 2019 and its contribution to local revenue of Makassar City in 2018. This was a descriptive study through a quantitative approach with cross sectional design. The observation was conducted on 21 major roads and the document review was performed by processing and analyzing the secondary data of the Regional Revenue Department of Makassar City 2018. Data were analyzed descriptively using IBM SPSS 22. This study found around $51 \%$ of 619 tobacco advertising (banner, billboard, name board, poster, pushcart, and video Tron) did not comply with the Local Regulation of South Sulawesi 1/2015. The violations were located in SFA (2\%); near schools and healthcare facilities (14\%); cut off the roads (16\%); the size $>72 \mathrm{~m}^{2}(6 \%)$; and near government offices (40\%). The contribution of tobacco advertising was only IDR 736,643,634,-., which was around $0.02 \%$ of the local revenue. The violation of tobacco advertising to the Local Regulation 1/2015 and a very small contribution to local revenue showed that Mayor Regulation on Total Tobacco Advertising, Promotion, and Sponsorship (TAPS) Ban should be carried out immediately to prevent children to be the target tobacco industries in Makassar City.
\end{abstract}

Keywords: tobacco advertising, TAPS contribution, local revenue

\section{INTRODUCTION}

Tobacco consumption in Indonesia has increased significantly by ranking second after China, while America, Russia , and Japan have decreased (Tobacco Control Support Center-Indonesia Public Health Association, 2020). Indonesia also ranked first among Asian countries with the highest prevalence of male smokers with a percentage of $76 \%$, while China and India with the larger population ranked $4^{\text {th }}(48 \%)$ and $17^{\text {th }}(20 \%)$ (DataLEADS/Asia News Network, 2017). This high consumption of tobacco was caused by various factors, namely increasing household income, population growth, low price of cigarettes, and the mechanization of the industry (Data and Information Center, 2018). In this country, the main form of tobacco consumption was smoking behavior with the prevalence of smokers age over 10 years reaching around $24.3 \%$ in 2018 , while the highest prevalence in Lampung Province $(28.1 \%)$ and the lowest in Papua Province (18.8\%) (National Institute of Health Research and Development, 2019b).

The highest prevalence of smoking behavior came from the poorest population group $(27 \%)$, where cigarettes were the second largest expenditure after rice, both in urban and rural areas (Indonesia Ministry of National Development Planning, 2019). Even though cigarettes have become a risk factor for death and disability, as well as causing economic losses of up to IDR 378.75 Trillion (Indonesia Ministry of National Development Planning, 2019; Non-Communicable Diseases Prevention and Control of Indonesia Ministry of Health, 2018a). Smoking behavior was also one of the contributors to the poverty line 
and the incidence of stunting among the children (Indonesia Ministry of National Development Planning, 2019; NonCommunicable Diseases Prevention and Control of Indonesia Ministry of Health, $2018 \mathrm{~b}$ ). The results of a study that was conducted by the Center for Health Economics and Policy Studies, the University of Indonesia in 2018 reported that the incidence of stunting was $5.5 \%$ higher among the children who had smoking parents (Non-Communicable Diseases Prevention and Control of Indonesia Ministry of Health, 2018b). It was also in line with the results of a study conducted in Bali Province in 2020 that smoking behavior among the parents would have a direct and an indirect impact on the child's growth process, especially for children aged 2-5 years (Sari and Resiyanthi, 2020).

The tobacco industry has also targeted children in its market. It was concluded from the increasing prevalence of child smokers in Indonesia. In the 5 years period from 2013 to 2018, tobacco consumption among smokers aged 10-18 years has increased by $126 \%$ from $7.2 \%$ to 9.1\% (Tobacco Control Support CenterIndonesia Public Health Association, 2020; National Institute of Health Research and Development, 2013, 2019b). Meanwhile, the government's target in the National Medium-Term Development Plan 20152019 should only be around $5.4 \%$ of child smokers by 2019 (Indonesia Ministry of National Development Planning, 2017). The difficulty of decreasing the prevalence of child smoking caused the indicators of smoking behavior to fail to be achieved in 2019.

Makassar City as the capital city of South Sulawesi Province and the location of this study also reported that the prevalence of smokers over 10 years was around $21.01 \%$ based on the results of Basic Health Research 2018 (National Institute of Health Research and Development, 2019a). Meanwhile, the proportion of age at first smoking in Makassar City was the highest in the age group 15-19 years, reaching around 50.83\% in 2018 (National Institute of Health Research and Development, $2019 b$ ). The average cigarette consumption among child smokers was around 8 cigarettes per day (Hasanuddin Contact, 2018).

The increasing of the child smokers prevalence in Makassar City was influenced by many factors, including tobacco advertisements, promotions, and sponsorship (TAPS) everywhere, easy to access cigarettes due to the price was cheap, can be bought in anywhere and by anyone, and considered smoking as a common thing (Lentera Anak Foundation, 2020a). According to the data in 2019, the students saw tobacco advertisements everywhere, including around $61 \%$ looking at outdoor, $36 \%$ viewing on the internet, $57 \%$ viewing on television, and $65 \%$ looking at a pointof-sale (WHO, 2019). A survey that conducted to the student in Makassar city 2018 reported that the students' impressions about tobacco advertisements were attractive (64\%), cool (59\%), and masculine (48\%) (Hasanuddin Contact, 2018).

The situation of child smokers was exacerbated due to there has been no sufficient regulations to protect child and adolescents from tobacco addiction and could decrease the prevalence of the beginner smokers, including in Makassar City. The Local Regulation of South Sulawesi No. 1 of 2015 and the Local Regulation of Makassar No.4 of 2013 concerning Smoke Free Areas (SFA) have not yet been optimal in protecting children and adolescents from tobacco exposure as well as TAPS (Government of Makassar City, 2014; Government of South Sulawesi, 2015). Based on the urgency in protecting children and adolescents from the tobacco industry targets, this study aimed to evaluate the violation of tobacco product billboards against the Local Regulation of South Sulawesi No. 1 of 2015 concerning SFA and to determine the contribution of TAPS to the local revenue in Makassar City in 2018. 


\section{METHOD}

This study was a descriptive study with a quantitative approach and crosssectional design. This study was undertaken in Makassar city in April 2019. This study was a subsection of the Tobacco Control and Non-Communicable Disease Prevention Research in Makassar City 2018-2019, which was undertaken by Hasanuddin Center for Tobacco Control and Non-Communicable Disease Prevention (Hasanuddin CONTACT), in collaboration with Global Environmental Health LAB (GehLAB). This study has acquired ethical approval from Northern Illinois University (NIU) number HS160174.

The data collection was undertaken through observation and document review. Observations were undertaken in 2019 to obtain scientific evidence regarding the location of tobacco advertisements and promotion, such as billboards, name boards, posters, pushcarts (often used by venders) "rombong", banners, and video tron. The observation was undertaken in the major road of Makassar city: ten national roads, eight provincial roads, and three protocol roads (as depicted in Table 1). The observer took the picture of tobacco advertisements as the documentation of this study. The observation was undertaken using an instrument in the form of an observation guide made on a digital platform, the Kobo Toolbox, to obtain the actual point of location for the distribution of tobacco product billboards, which were then presented in map form.

Meanwhile, the document review was undertaken through secondary data processing to determine the contribution of TAPS to the local revenue of Makassar City in 2018. The secondary data were obtained from the Regional Revenue Agency of Makassar City in 2018, while data related to the amount of local revenue of Makassar
City in 2018 were obtained from the official website of the Government of Makassar City. Finally, the data from the observation and document review were analyzed descriptively using the statistical analysis software.

\section{RESULTS}



Figure 1. Distribution of Tobacco Product Advertising in the All Major Roads of Makassar City in year 2019

The first step of the study was undertaken an observation of tobacco billboards product on the major roads in Makassar City. The observation was only undertaken on the major road since the Government Regulation No. 1092012 and the Local Regulation of South Sulawesi No. 12015 only regulated the prohibition of tobacco advertisements in such road category.

According to the result of the observations, there were 619 tobacco billboards in 21 major roads in Makassar city: ten national roads, eight provincial roads, and three protocol roads (as depicted in Table 1). The tobacco product billboards were mostly located on provincial roads with a percentage of approximately $37.1 \%$ $(\mathrm{n}=230)$, in the protocol roads with a percentage of approximately $32.6 \%(\mathrm{n}=$ 202) and the third was national roads with a percentage of approximately $30.2 \%(\mathrm{n}=$ 187) (as depicted in Table 2). 
Table 1. The Major Roads of Observation Location in Makassar in 2019

\begin{tabular}{ll}
\hline Road Categories & Name of the Roads \\
\hline National Road & Gn. Bawakaraeng \\
$(\mathrm{n}=10)$ & Masjid Raya \\
& Bulusaraung \\
& Ahmad Yani \\
& Riburane \\
& Nusantara \\
& Ujung Pandang \\
& Veteran Utara \\
& Veteran Selatan \\
& Sultan Alauddin \\
\hline Province Road (n & Dr. Ratulangi \\
$=8)$ & Jend. Sudirman \\
& Syekh Yusuf \\
& Tamangapa Raya \\
& Antang Raya \\
& Dr. Leimena \\
& A. Mappainga \\
& Abdul Kudus \\
\hline Protocol Road (n & AP. Pettarani \\
$=3)$ & Urip Sumihardjo \\
& Perintis \\
& Kemerdekaan \\
\hline
\end{tabular}

Source: Primary Data, 2019

Table 2. Frequency of Tobacco Product Advertising by Major Road Categories in Makassar City 2019

\begin{tabular}{lcc}
\hline $\begin{array}{c}\text { Major } \\
\text { Road } \\
\text { Categories }\end{array}$ & $\begin{array}{c}\text { Subtotal } \\
(\mathbf{n})\end{array}$ & $\begin{array}{c}\text { Percentage } \\
(\boldsymbol{\%})\end{array}$ \\
\hline Provincial & 230 & 37.1 \\
Protocol & 202 & 32.6 \\
National & 187 & 30.2 \\
\hline \multicolumn{1}{c}{ Total } & $\mathbf{6 1 9}$ & $\mathbf{1 0 0 . 0 \%}$ \\
\hline Source: Primary
\end{tabular}

Source: Primary Data, 2019

Based on Table 3, it was discovered that banner was the most used tobacco advertisement type at the time of observation with a percentage of approximately $33.6 \%(\mathrm{n}=208)$, while horizontal banner was not found at the time of observation. The type of tobacco advertisement, name board, located in the front of shops, kiosks, stalls, café, or coffee shop also was most often found after the banner with the percentage of approximately $30.4 \%(n=188)$.



Figure 2. Name Board of Tobacco Product at Coffee Shop in Makassar 2019

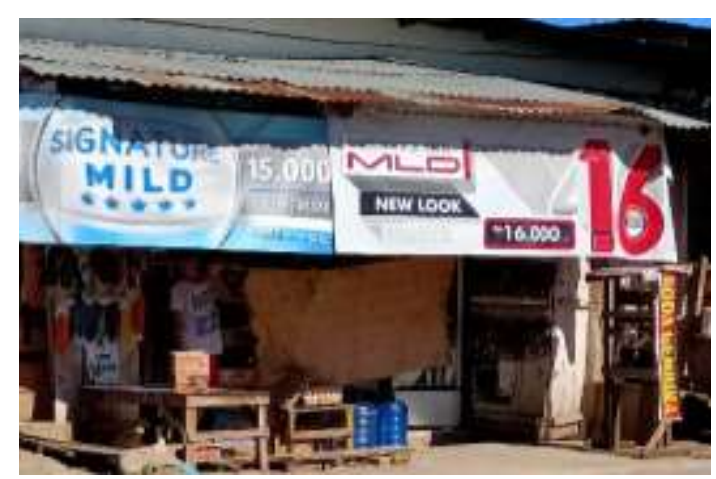

Figure 3. Banner of Tobacco Product at a Stall in Makassar City 2019

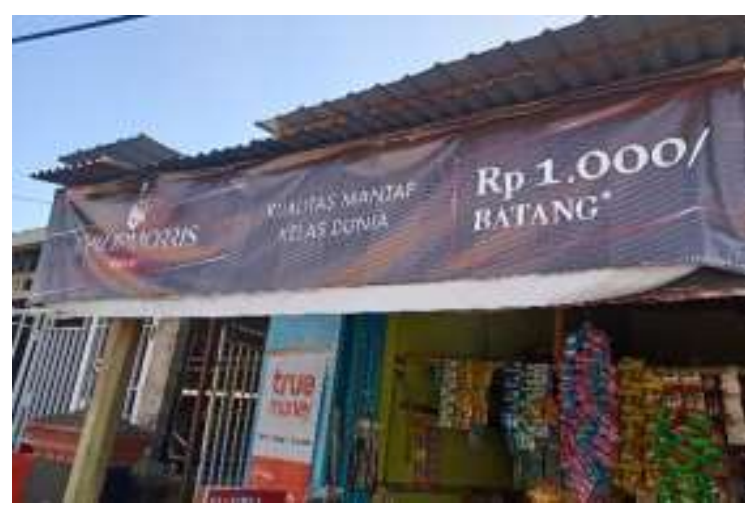

Figure 4. One of the Tobacco Product Advertising Not Including Health Warnings in Makassar City 2019 
Table 3. Frequency of Tobacco Product Advertising by Type of Advertisements in Makassar City 2019

\begin{tabular}{lcc}
\hline $\begin{array}{c}\text { Type of } \\
\text { Advertisement }\end{array}$ & $\begin{array}{c}\text { Subtotal } \\
(\mathbf{n})\end{array}$ & $\begin{array}{c}\text { Percentage } \\
(\mathbf{\%})\end{array}$ \\
\hline Banners & 208 & 33.6 \\
Name Board & 188 & 30.4 \\
Poster & 124 & 20.0 \\
Billboards & 91 & 14.7 \\
Videotron & 5 & 0.8 \\
Horizontal & 0 & 0 \\
Banner & & \\
\hline \multicolumn{1}{c}{ Total } & $\mathbf{6 1 9}$ & $\mathbf{1 0 0 . 0 \%}$ \\
\hline
\end{tabular}

Source: Primary Data, 2019

The results of observations also showed that many billboards still violated or not comply the Local Regulation of South Sulawesi No. 1 of 2015 concerning SFA. These violations can be seen in Table 4 and Table 5. Approximately 49.9\% $(\mathrm{n}=$ 309) of tobacco product billboards violated Article 18 Paragraph (2) concerning the provisions of tobacco product billboards and around $50.1 \%(\mathrm{n}=316)$ tobacco product billboards violated Article 18 Paragraph (3) regarding the provisions for the installation of tobacco billboards.

Table 4 showed forms of violations of tobacco billboards in accordance to Article 18 (2): children involvement, adolescents and/or pregnant women in the form of picture and/or text (32.0\%); demonstrating, using, and/or displaying the form of the cigarettes $(28.8 \%)$; not including the symbol or the text "18+" $(6.6 \%)$; describing or suggesting that smoking provided health benefits $(5.7 \%)$; and not including health warnings in the form of pictures and text (5.5\%).

Meanwhile, Table 5 showed the forms of violation of tobacco product billboards against the provisions of Article
18 (3). They were located inside SFA (2.3\%); closed to schools and health service facilities (13.6\%); cut off/across the road $(16.5 \%)$; the size is $>72 \mathrm{~m}^{2}(5.8 \%)$; and located in front of or beside the local government offices (39.6\%).



Figure 5. Tobacco Product Ads in Front of Hospital in Makassar 2019

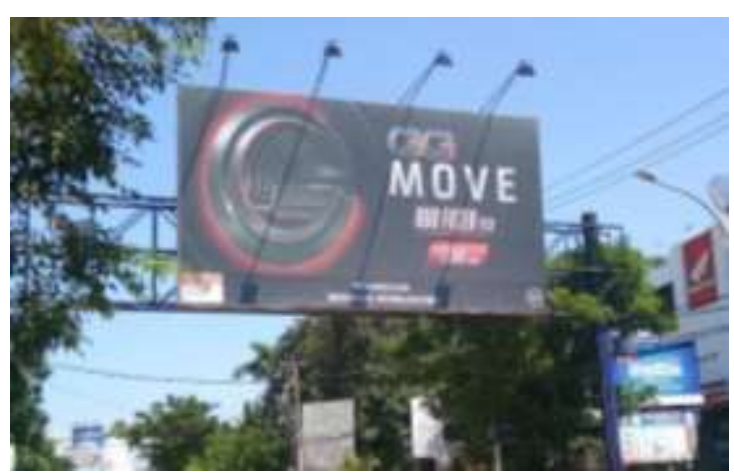

Figure 6. Tobacco Product Ads Across Major Road in Makassar 2019

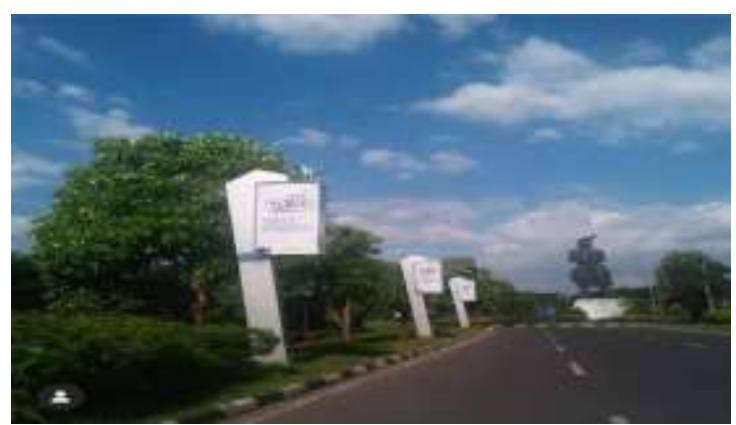

Figure 7. Tobacco Product Advertising at Entrance Gate of Sultan Hasanuddin Airport 2019 
Table 4. The Compliance of Tobacco Advertising Criteria to Local Regulation of South Sulawesi No. 1 of 2015 Signage on SFA Article 3(2) in Makassar City 2019

\begin{tabular}{|c|c|c|c|c|}
\hline \multirow{2}{*}{$\begin{array}{l}\text { Tobacco Products } \\
\text { Advertising Criteria }\end{array}$} & \multicolumn{2}{|c|}{ Comply } & \multicolumn{2}{|c|}{ Not Comply } \\
\hline & $\mathbf{n}$ & $\%$ & $\mathbf{n}$ & $\%$ \\
\hline $\begin{array}{l}\text { There is a Health warning } \\
\text { (picture and text) }\end{array}$ & 585 & 94.5 & 34 & 5.5 \\
\hline There is sign/text "18+" & 578 & 93.4 & 41 & 6.6 \\
\hline $\begin{array}{l}\text { Not displaying, using and/or } \\
\text { presenting the form of } \\
\text { cigarettes }\end{array}$ & 441 & 71.2 & 178 & 28.8 \\
\hline $\begin{array}{l}\text { Not suggesting that smoking } \\
\text { provides health benefits }\end{array}$ & 584 & 94.3 & 35 & 5.7 \\
\hline $\begin{array}{l}\text { Not showing the image of } \\
\text { children, adolescents and/or } \\
\text { pregnant women in } \\
\text { picture/text }\end{array}$ & 421 & 68.0 & 198 & 32.0 \\
\hline Total & 310 & $50.1 \%$ & 309 & $49.9 \%$ \\
\hline
\end{tabular}

Source: Primary Data, 2019

Table 5. The Compliance of Tobacco Product Advertising Installation to Local Regulation of South Sulawesi No. 1 of 2015 on SFA Article 3(3) in Makassar City 2019

\begin{tabular}{lcccc}
\hline $\begin{array}{l}\text { Criteria for Tobacco } \\
\text { Advertising Installation }\end{array}$ & $\mathbf{n}$ & $\mathbf{\%}$ & $\mathbf{n}$ & $\mathbf{\%}$ \\
\hline $\begin{array}{l}\text { Not placed inside smoke-free } \\
\text { areas }\end{array}$ & 608 & 97.7 & 14 & 2.3 \\
\hline $\begin{array}{l}\text { Not placed on the major roads } \\
\text { closed to the schools and/or } \\
\text { healthcare facilities }\end{array}$ & 535 & 86.4 & 84 & 13.6 \\
\hline $\begin{array}{l}\text { Placed parallel to the shoulder } \\
\text { of the road and not cut off or } \\
\text { cross the roads }\end{array}$ & 517 & 83.5 & 102 & 16.5 \\
\hline Not exceed the size of 72 m ${ }^{2}$ & 583 & 94.2 & 36 & 5.8 \\
\hline $\begin{array}{l}\text { Not placed in front of/next to } \\
\text { the government office building }\end{array}$ & 374 & 60.4 & 245 & 39.6 \\
\hline \multicolumn{1}{c}{ Total } & $\mathbf{3 0 3}$ & $\mathbf{4 8 . 9 \%}$ & $\mathbf{3 1 6}$ & $\mathbf{5 1 . 1 \%}$ \\
\hline
\end{tabular}

Source: Primary Data, 2019

After conducting the observation of tobacco product billboards, then the processing and analysis of the secondary data from the Regional Revenue Agency of Makassar City was undertaken. The aim was to determine the contribution of tobacco product billboards through taxes and retribution to the local revenue of Makassar city in 2018.

The data from Regional Revenue
Agency of Makassar City in 2018 showed that around 176 cigarette product billboards were recorded on all roads in Makassar City with total taxes and fees of Rp736,643,634.00. The total local revenue of Makassar City in 2018 was IDR 1,483,713,060,000.00. Therefore, the contribution of tobacco product billboards was only about $0.02 \%$. 


\section{DISCUSSION}

Tobacco industry utilized all kinds of media to promote their products, whether in print, electronic, online, or outdoor media. Outdoor media included billboard, poster, video Tron, sticker, banner, neon box, decorative lights, signboard/board name, hot air balloon, cart, house, substation, tents, bus, car, motorbike, bus stop, and tire covers, which were located around schools, hospitals, offices, malls, tourist attractions, restaurants, and children's playgrounds. The tobacco industry utilized an advertising subliminal strategy through picture with a positive image that was shown repeatedly, thus the subconscious of the children normalized tobacco products (Lentera Anak Foundation, 2020a).

According to the observations, it was discovered that there were 619 tobacco advertising on ten national roads, eight provincial roads, and three protocol roads in 2018 (as depicted in Table 1). In the same year, it was reported that the prevalence of smokers aged above 10 years reached about $21.01 \%$ with the highest proportion of first smoking age group (10-15 years) reaching around $51 \%$ (National Institute of Health Research and Development, 2019b). The large number of tobacco product advertising located on major roads of Makassar City was an emergency issue due to many studies that proved the impact of tobacco advertising exposures on smoking behavior among the children.

Several studies reported that there was a significant correlation between tobacco advertising exposure and an increasing smoking behavior prevalence, especially beginner smokers (such as children and adolescents). A study in Nigeria reported that there was a significant association between exposure to cigarette advertisements and an increasing of tobacco use among Nigerian adolescents (AOR: 1.18 ; $95 \%$ CI 1.03 to 1.34 ) (ChidoAmajuoyi et al., 2017). This result was in line with the study in Myanmar that tobacco advertising was a strong risk factor for the increasing of smoking behavior among high school students (AOR 0.17; 95\% CI 0.10 to 0.30) (Cho et al., 2020).

Generally, the government had the strength and opportunity to support the implementation of tobacco control in Indonesia. There was Indonesia Minister of Health Regulation No. 40 of 2013 concerning the Roadmap for Controlling the Impact of Tobacco Consumption for Health by establishing smoke-free areas, increasing tobacco taxes, banning tobacco advertising and sponsorship, and pictorial health warnings (Indonesia Ministry of Health, 2013). The total tobacco advertising, promotion, and sponsorship (TAPS) ban was also one of the policy directions and strategies in the National Medium-Term Development Plan 20202024 (Indonesia Ministry of National Development Planning, 2019). Unfortunately, until the end of 2020, no sufficient regulations implemented to protect children and adolescents from the exposure of tobacco product advertising.

Moreover, Local Regulation of Makassar City No. 4 of 2013 on SmokeFree Areas does not include TAPS ban in major roads, as stated in Government Regulation No. 109 of 2021 and Local Regulation of South Sulawesi No. 1 of 2015 concerning Smoke-Free Areas Article 18 Paragraph (3), (4), and (5). It was different from European countries which have total banned all types of TAPS, both on television, radio and billboards (Münzel et al., 2020).

In Indonesia, there were around $85 \%$ of 345 regencies/cities that have regulate TAPS Ban in their local regulation of smoke-free areas, such as Bogor city and Depok city (Tobacco Control Support Center-Indonesia Public Health Association, 2020). There were also some region in Indonesia that have issue regulation or policy for total ban tobacco product billboard in the form of governor regulation such as DKI Jakarta, major regulation such as Denpasar City, and 
regent regulation such as Kulon Progo regency. So that, the local government of Makassar City should immediately issue a regulation or policy concerning TAPS Ban, especially for tobacco product billboards. The aim is to protect children and adolescents from the negative impact of tobacco product advertising exposure. So that, the prevalence of child and adolescent smokers can be reduced in Makassar City.

Although in Local Regulation of Makassar City No. 4 of 2013 does not yet regulate the prohibition of tobacco product billboards, the Government Regulation No. 109 of 2012 and Local Regulation of South Sulawesi No. 1 of 2015 can be used as a reference in controlling tobacco product billboards in Makassar City. The provisions regarding tobacco product advertisements and their installation have been regulated in Local Regulation of South Sulawesi No. 1 of 2015 in Article 18.

Based on the observation, this study found that some tobacco product advertising did not comply to Local Regulation of South Sulawesi No. 1 of 2015 Article 18 Paragraph (2) and (3). The violation of tobacco product billboards in Article 18 Paragraph (2) concerning the provisions of tobacco product billboards with percentage of around $49.9 \%$. The provisions that were violated as follows: children involvement, adolescents, and/or pregnant women in the form of pictures and/or text (32.0\%); demonstrating, using, and/or displaying the form of cigarettes $(28.8 \%)$; did not include the sign or the words of "18+" in the advertisement $(6.6 \%)$; describing or suggesting that smoking provided health benefits $(5.7 \%)$; and did not include health warnings in the form of picture and text in the advertisements $(5.5 \%)$.

The result of this study in line with a survey that conducted in DKI Jakarta on outdoor media for tobacco products. This study reported the violations of tobacco product advertising to Regulation of Governor DKI Jakarta No. 1 of 2015, among others were not including pictorial warnings (11\%) and age restrictions (12\%), using animation (1\%) and cultural references $(5 \%)$, and using other designations that referred to tobacco product brands (Forum of Jakarta Citizen/FAKTA, 2015). There were still many violations to local regulations on smoke-free area by the tobacco industry so the local government should be stricter in enforcing the regulations, especially in imposing sanctions.

The violation by displaying symbols or images that referred to children and adolescents has made it clear that this industry was targeting children and adolescents in its market. Until now, there were still many events such as music concerts sponsored by the tobacco industry in Makassar city. The temptation to try cigarettes was even greater if children and adolescents attended those music concerts due to the distribution of free cigarettes at the venue entrance. However, tobacco industries denied targeting children and adolescents, but in fact they employed advertising as one of several important and interlocking ingredients that nurture smoking behavior among adolescents and children (WHO, n.d.).

Apart from Article 18 Paragraph (2), the violations also occurred in Article 18 Paragraph (3) concerning the provisions for the installation of tobacco product billboards with percentage of around $50.1 \%$. The violations were located inside smoke-free areas (2.3\%); closed to schools and healthcare facilities (13.6\%); cut off/crossed the major road (16.5\%); measured up to $72 \mathrm{~m}^{2}$ (5.8\%); and located in front of or beside local government office $(39.6 \%)$.

This study in line with a survey of outdoor media for tobacco products in DKI Jakarta 2015 which reported violations of Governor DKI Jakarta Regulation No. 1 of 2015, including located inside smoke-free areas, located on the access road towards smoke-free areas (place of worships $=94 \%$; schools $=91 \%$ ) (Forum of Jakarta Citizen/FAKTA, 2015). Those type of 
violations also reported in a study in Surabaya city that within $300 \mathrm{~m}$ of schools $(27 \%)$ and campuses $(31 \%)$ there were tobacco advertisements (Megatsari et al., 2019). The percentage of the visibility of tobacco advertisements within $300 \mathrm{~m}$ from schools in Semarang city was higher, which was around 74\% (Nurjanah et al., 2020).

Tobacco product advertising that located close to smoke-free area, especially the school also happened in United States. The study in United States reported around $25 \%$ tobacco advertising located about 500 feet from a school, playground, or church and around $40 \%$ tobacco advertising located in major roads (Scott et al., 2008). Based on the result of these studies, it was concluded that currently children were being attacked by tobacco advertisements due to tobacco product billboards exposure in everywhere. Not only near schools, but also along the major roads, public transportation, city parks, sports venues and tourist attractions (Lentera Anak Foundation, 2020a). The placement of tobacco product advertising showed the intended marketing targets (Forum of Jakarta Citizen/FAKTA, 2015). Many tobacco product billboards close to the schools, even violated the regulation, proved that the children and adolescents have become tobacco industry target. Therefore, local government needs to optimize the monitoring and evaluation of their local regulation, especially on smokefree areas and ban TAPS.

The evidence found in this study should serve as a reference to develop total ban TAPS in Makassar city in order to reduce the exposure of tobacco product marketing among the children and adolescents. It was in line with the recommendation of a study in Nigeria that the implementation of a comprehensive ban TAPS in all types of media was effective to prevent tobacco consumption among youth in Nigeria (Chido-Amajuoyi et al., 2017). In Indonesia until March 2020, as many as 16 regencies/cities have banned TAPS in various forms of regulations (appeal letter, instruction letter, regent regulation, mayor regulation, and local regulation), namely DKI Jakarta, Bogor City, Depok City, Kulon Progo Regency, and Denpasar City (Lentera Anak Foundation, 2020b; National Tobacco Control Committee, 2019).

This study was conducted also to examine the contribution of TAPS through tobacco product billboard taxes and retribution to local revenue of Makassar City in 2018. It was done to strengthen the urgency of ratifying the Draft Mayor Regulation concerning the Prohibition of Tobacco Product Billboards in Makassar City which has currently been reviewed by the Law and Human Rights Division of Makassar City.

For information, the tobacco tax was one of the local taxes managed by the provincial and regency/city governments based on Law Number 28 of 2009 which was obtained from cigarette excise and was coercive (Maulida, 2018). The tax would be managed by the local government and allocated for public purposes, such as procurement or improvement of local infrastructure (Musdalifah et al., 2020).

Data from Regional Revenue Agency of Makassar City in 2018 showed that there were about 176 tobacco product billboards recorded on all roads in Makassar City. Total tax and retribution of tobacco product billboard was around IDR 736 million. Meanwhile the total of local revenue of Makassar City in 2018 was around IDR 3.4 billion. Hence, the contribution of taxes and retribution of tobacco product advertisements to local revenue of Makassar City in 2018 was only around $0.02 \%$ (See Table 4). This amount was very small, even insignificant. Thus, the total ban of tobacco billboards will not have any meaning to the local revenue of Makassar City.

The small contribution of tobacco advertising to local revenue has caused a number of regions banning tobacco product advertisements, namely DKI Jakarta, Bogor City, Kulon Progo Regency, and Denpasar City. After banning tobacco 
advertisements, these areas actually experienced an increase in their local revenue. Denpasar city experienced increasing local revenue by $10.1 \%$ from IDR 658 billion in 2013 to IDR 776 billion in 2015. This happened because the contribution of tobacco advertisements to local revenue in Denpasar was only $0.18 \%$ in 2013 (Artawan Eka Putra et al., 2017). In addition, Bogor city in 2008 (before Major Regulation on the Prohibition of Tobacco Product Billboards took effect in 2014) had local revenue about IDR 97 million with 372 tobacco advertising billboards increasing to IDR 784 billion with 0 tobacco advertising billboards in 2016 (or 2 years after Major Regulation enforced) (Bogor City Government, 2017). It means that banning tobacco advertisements through the ratification of Regulation on Ban Tobacco Product Billboards will not have any impact, especially on local revenue because tobacco advertisements will be replaced by advertisements from other products.

Therefore, local government of Makassar City is expected to take firm action against tobacco product advertisements that violated and immediately ratify the Mayor Regulation for ban tobacco product billboards in Makassar City, hence the public health status can be further improved and children are no longer as the target of tobacco industry in Makassar City.

\section{CONCLUSION}

This study found that there was still tobacco industry not complying Local Regulation of South Sulawesi No. 1 of 2015 on SFA in Article 18 Paragraph (2) and (3), especially in terms of advertisements that cross/cut roads and were near schools/healthcare facilities. Therefore, it is expected that local government of Makassar City will be serious in monitoring the compliance of tobacco product billboards, including the enforcement of sanctions for anyone who violated it. If necessary, it is better to take action to reduce noncompliant tobacco advertising. Moreover, the results of this study also proved that the contribution of tobacco advertisements to local revenue in Makassar was very small or insignificant (around 0.02\%).

Hence, local government of Makassar City was expected to immediately ratify the Draft Mayor Regulation concerning the Prohibition of Tobacco Product Billboards, thus we can successful increasing local revenue as well as other regencies/cities after ban tobacco advertising in order to enjoy the demographic bonus 2020-2030 in Makassar City.

\section{REFERENCE}

Artawan Eka Putra, I.W.G., Astuti, P., Duana, I.M., Suarjana, K., Mulyawan, H. and Bam, T. 2017. The Impact of the Moratorium on Tobacco Advertising, Promotion, and Sponsorship on Compliance with Local Regulations on SFA and Local Revenue in Denpasar City. $3^{\text {rd }}$ Indonesian Conference on Tobacco or Health. Yogyakarta, Indonesia, 24-27 November 2016. Denpasar: Tobacco Control Initiative (BTCI).

Bogor City Government, 2017. Implementation and Enforcement of the Local Regulation on SFA and the Influence of Advertising in Bogor City. [Presentation] In: $6^{\text {th }}$ Indonesian Conference on Tobacco or Health.

Chido-Amajuoyi, O.G., Mantey, D.S., Clendennen, S.L. and Pérez, A., 2017. Association of Tobacco Advertising, Promotion and Sponsorship (TAPS) Exposure and Cigarette Use Among Nigerian Adolescents: Implications for Current Practices, Products and Policies. BMJ Global Health 2017, [e-journal] 2(3), pp.1-9. 10.1136/ bmjgh-2017-000357.

Cho, S.M., Saw, Y.M., Latt, N.N., Saw, 
T.N., Htet, H., Khaing, M., Than, T.M., Win, E.M., Aung, Z.Z., Kariya, T., Yamamoto, E. and Hamajima, N., 2020. CrossSectional Study on Tobacco Advertising, Promotion and Sponsorship (TAPS) and Violations of Tobacco Sale Regulations in Myanmar: Do These Factors Affect Current Tobacco Use Among Myanmar High School Students?. BMJ Open, [e-journal] 10(2), pp.110. 10.1136/bmjopen-2019-031933.

Data and Information Center, I.M. of H., 2018. The Situation of Tobacco Consumption in Indonesia. [online] [Accessed 1 December 2020].

DataLEADS/Asia News Network, 2017. Indonesians Top Smokers in World. [press release] 30 August 2017. [Accessed 10 December 2020].

Forum of Jakarta Citizen/FAKTA, 2015. Outdoor Media Survey in Jakarta. [pdf] Jakarta: Forum of Jakarta Citizen/FAKTA [Accessed 10 December 2020].

Government of Makassar City, 2014. Local Regulation of Makassar City No. 4 of 2013 on Smoke-Free Area.

Government of South Sulawesi, 2015. Local Regulation of South Sulawesi Province No. 1 of 2015 on SmokeFree Area.

Hasanuddin Contact, 2018. Tobacco Control and NCD Prevention Survey in Makassar City 2018. Makassar: Hasanuddin Contact.

Indonesia Ministry of Health, 2013. Indonesia Minister of Health Regulation No. 40 of 2013 concerning the Roadmap for Controlling the Impact of Tobacco Consumption for Health.

Indonesia Ministry of National Development Planning, 2017. MidTerm Evaluation of The National Medium-Term Development Plan 2015-2019. [pdf] Jakarta: Indonesia Ministry of National Development Planning. [Accessed 10 December
2020].

Indonesia Ministry of National Development Planning, 2019. The National Medium-Term Development Plan 2020-2024. [pdf] Jakarta: Indonesia Ministry of National Development Planning. [Accessed 10 December 2020].

Lentera Anak Foundation, 2020a. Child Smoker Emergency, Tobacco Advertising Invasion and Weak Regulations. [press release] 7 October 2020. [Accessed 10 December 2020].

Lentera Anak Foundation, 2020b. Commitment of Central-Regional Leaders and Support from All Key Elements of Community was the Successful Key for Enforcement of Smoke-Free Areas and TAPS Ban. [press release] 16 July 2020. [Accessed 10 December 2020].

Maulida, R., 2018. Definition of Local Tax. [online] [Accessed 3 July 2020].

Megatsari, H., Ridlo, I.A., Amir, V. and Kusuma, D., 2019. Visibility and Hotspots of Outdoor Tobacco Advertisement Around Educational Facilities Without an Advertising Ban: Geospatial Analysis in Surabaya City, Indonesia. Tobacco Prevention \& Cessation, [e-journal] 5(32), pp.1-6. https://doi.org/10.18332/tpc/11246 2.

Münzel, T., Hahad, O., Kuntic, M., Keaney Jr, J.F., Deanfield, J.E. and Daiber, A., 2020. Effects of Tobacco Cigarettes, E-cigarettes, and Waterpipe Smoking on Endothelial Function and Clinical Outcomes. European Heart Journal, [ejournal] 41(41), pp.4057-4070. 10.1093/eurheartj/ehaa460.

Musdalifah, S., Ernitawati, Y., Ikhwan, S., Akuntansi, S., Manajemen, P.S., Restoran, P. and Reklame, P., 2020. Acceptance Rate of Hotel Tax, Restaurant Tax, and Billboard Tax on Local Revenue (A Study in 
Management of Regional Revenue, Finance, and Assets Office of Brebes 2014-2018). Journal of Accounting and Finance (JACFIN), [online] 1(1), pp.37-51.

National Institute of Health Research and Development, I.M. of H., 2013. Basic Health Research 2013. [online] [Accessed 3 July 2020].

National Institute of Health Research and Development, I.M. of H., 2019a. Basic Health Research: South Sulawesi Report. [online] [Accessed 3 July 2020].

National Institute of Health Research and Development, I.M. of H., 2019b. Basic Health Research 2018. [online] [Accessed 3 July 2020].

National Tobacco Control Committee, 2019. Stop Tobacco Advertising. [online] [Accessed 3 July 2020].

Non-Communicable Diseases Prevention and Control of Indonesia Ministry of Health, 2018a. The Dilemma of Tobacco Industry in Indonesia. [press release] 1 October 2018. [Accessed 10 August 2020].

Non-Communicable Diseases Prevention and Control of Indonesia Ministry of Health, 2018b. Tobacco Consumption Causing Stunting among the Children. [press release] 25 June 2018. [Accessed 10 December 2020].

Nurjanah, N., Manglapy, Y., Handayani, S., Ahsan, A., Sutomo, R., Sari, F., Dewi, T., Chang, P. and Kusuma, D., 2020. Density of tobacco advertising around schools. The International Journal of Tuberculosis and Lung Disease, [ejournal] 24(7), pp.674-680. 10.5588/ijtld.19.0574.

Sari, N.A.M.E. and Resiyanthi, K.A., 2020. The Association between Parents' Smoking Behavior and Stunting. Journal of Child Nursing, [ejournal] 3(2), pp.24-30. http://dx.doi.org/10.32584/jika.v3i2 .773 .
Scott, M., Cohen, D., Schonlau, M., Farley, T. and Bluthenthal, R., 2008. Alcohol and Tobacco Marketing. Evaluating Compliance with Outdoor Advertising Guidelines. American journal of preventive medicine, [e-journal] 35(3), pp.203209.

10.1016/j.amepre.2008.05.026.

Tobacco Control Support Center-Indonesia Public Health Association, 2020. Indonesia Tobacco Atlas 2020. [online] Jakarta: Tobacco Control Support Center-Indonesia Public Health Association.

WHO, 2019. Factsheet Global Youth Tobacco Survey of Indonesia 2019. [pdf] Indonesia: WHO. [Accessed 10 December 2020].

WHO, n.d. Tobacco Explained: The Truth about The Tobacco Industry in Its Own Words. [pdf] WHO. [Accessed 1 January 2021]. 